\title{
Ileal amino acid digestibilities in pigs of barley-based diets with inclusion of lucerne (Medicago sativa), white clover (Trifolium repens), red clover (Trifolium pratense) or perennial ryegrass (Lolium perenne)
}

\author{
M. Reverter, T. Lundh and J. E. Lindberg* \\ Department of Animal Nutrition and Management, Swedish University of Agricultural Sciences, PO Box 7024, \\ S-750 07 Uppsala, Sweden
}

(Received 16 October 1998 - Revised 8 March 1999 - Accepted 12 April 1999)

\begin{abstract}
Two experiments were performed with post-valve T-cannulated growing pigs, using five animals in each experiment in a change-over design to evaluate the effect of inclusion of four different dried forage meals on ileal crude protein (CP) and amino acid (AA) digestibilities. The control diets $(\mathrm{C} 1$ and $\mathrm{C} 2)$ were barley-based and the experimental diets were formulated by replacing the barley with 100 or $200 \mathrm{~g} / \mathrm{kg}$ of either lucerne (Medicago sativa) or white clover (Trifolium repens) meal in Expt 1 and red clover (Trifolium pratense) or perennial ryegrass (Lolium perenne $)$ meal in Expt 2. A decrease $(P<0.05)$ in the apparent ileal digestibility of $\mathrm{CP}$ and most of the essential and nonessential AA was found with the inclusion of lucerne, white clover and perennial ryegrass meal in the barley-based diets. When red clover meal was included, only the apparent ileal digestibilities of $\mathrm{CP}$, leucine, phenylalanine, tyrosine and glutamic acid were found to decrease $(P<0 \cdot 05)$. The estimated apparent ileal digestibilities of most essential AA in the forage meals were lower than in the barley-based diets. The ileal flow of glucosamine and ornithine was found to increase $(P<0.05)$ with increasing proportion of fibre in the diet, suggesting an increase in endogenous $\mathrm{N}$ secretions and small-intestinal microbial activity. With the minor changes found for ileal essential AA digestibilities with forage meal inclusion in the diet the present data confirm the potential of forage meals as a source of protein in pig diets.
\end{abstract}

Amino acids: Dietary fibre: Glucosamine: Forages

Forages are significant potential sources of protein and energy in animal food production. They may be grown widely, and improve the sustainability of cropping systems by growing grass and/or legumes instead of a monoculture of cereals. With the increasing development of organic pigmeat production, and also of various forms of ad libitum and free-choice feeding systems for pigs, forages may be of increasing interest as a valuable dietary ingredient in the pig industry. One of the major concerns is the high content of fibre in forages, as feeding high-fibre diets to pigs has long been associated with reduced nutrient digestibility (Just, $1982 a, b$; Graham, 1988) and impaired daily gain in growing pigs (Frank et al. 1983). However, the chemical composition and structure of the plant fibre varies with the fibre source (Van Soest, 1978; Åman \& Graham, 1990), with variable effects on the performance due to differences in the pigs' ability to utilize the fibre (King \& Taverner, 1975; Thomke, 1986; Low, 1993).

Recent studies have shown that forage meal inclusion in barley-based diets for growing pigs reduced both the ileal
(Lindberg \& Cortova, 1995; Andersson \& Lindberg, $1997 a, b)$ and total gastrointestinal tract (Lindberg et al. 1995; Lindberg \& Andersson, 1998) digestibilities of nutrients and energy. However, the depression in total gastrointestinal tract digestibility of energy was less pronounced with forage fibre inclusion in the diet compared with cereal fibre (Lindberg \& Andersson, 1998). This suggests that pigs have the capacity to utilize forage fibre to a greater extent than cereal fibre.

Despite the reduction in nutrient and energy digestibility, $\mathrm{N}$ utilization was improved as a result of forage meal inclusion in the diet (Lindberg \& Cortova, 1995). Earlier studies with growing pigs fed on the same diets as in the present work showed that $\mathrm{N}$ retention and $\mathrm{N}$ utilization tended to increase after the inclusion of forage meal (Lindberg \& Andersson, 1998). The excretion of faecal $\mathrm{N}$ increased due to a higher $\mathrm{N}$ intake in combination with a reduction in $\mathrm{N}$ digestibility and also due to an increase in fermentation of carbohydrates reaching the hindgut (Sauer et al. 1980; Beames \& Eggum, 1981). In contrast, urinary N 
Table 1. Chemical composition ( $\mathrm{g} / \mathrm{kg} \mathrm{DM})$ and mean daily intake $(\mathrm{g} / \mathrm{d})$ of DM and crude protein of control and experimental diets in experiments 1 and 2

\begin{tabular}{|c|c|c|c|c|c|c|c|c|}
\hline & Lucerne & White clover & \multicolumn{6}{|c|}{ Diets } \\
\hline \multicolumn{9}{|l|}{ Expt 1} \\
\hline Crude protein & 174 & 241 & 116 & 121 & 128 & 127 & 139 & \\
\hline Crude fat & 17 & 29 & 25 & 23 & 23 & 24 & 26 & \\
\hline Starch & 1 & 6 & 553 & 494 & 436 & 495 & 437 & \\
\hline Klason lignin & 80 & 71 & 12 & 19 & 26 & 18 & 24 & \\
\hline \multirow{4}{*}{$\begin{array}{l}\text { Mean daily intake } \\
\text { DM } \\
\text { Crude protein }\end{array}$} & & & & & & & & \\
\hline & & & 1791 & 1771 & 1735 & 1794 & 1705 & 35.5 \\
\hline & & & $208^{d}$ & $214^{\mathrm{cd}}$ & $222^{b c}$ & $228^{a b}$ & $238^{\mathrm{a}}$ & 4.5 \\
\hline & & & \multicolumn{6}{|c|}{ Diets } \\
\hline \multicolumn{9}{|l|}{ Expt 2} \\
\hline Crude protein & 215 & 152 & 116 & 124 & 136 & 120 & 123 & \\
\hline Crude fat & 27 & 27 & 24 & 26 & 26 & 24 & 26 & \\
\hline Starch & 2 & 0 & 564 & 505 & 447 & 503 & 443 & \\
\hline Sugars & 13 & 29 & 3 & 3 & 5 & 3 & 5 & \\
\hline Dietary fibre & 339 & 431 & 152 & 170 & 188 & 179 & 206 & \\
\hline NDF & 347 & 497 & 166 & 173 & 191 & 183 & 221 & \\
\hline Klason lignin & 50 & 45 & 12 & 16 & 20 & 16 & 19 & \\
\hline \multicolumn{9}{|l|}{ Mean daily intake } \\
\hline DM & & & $1940^{b}$ & $1939^{b}$ & $1944^{\mathrm{ab}}$ & $1942^{b}$ & $1950^{\mathrm{a}}$ & $2 \cdot 0$ \\
\hline Crude protein & & & $225^{d}$ & $239^{b}$ & $263^{a}$ & $233^{c}$ & $238^{\mathrm{b}}$ & $1 \cdot 3$ \\
\hline
\end{tabular}

NDF, neutral-detergent fibre.

$\mathrm{a}, \mathrm{b}, \mathrm{c}, \mathrm{d}$ Mean values within a row not sharing a common superscript letter were significantly different $(P<0.05)$.

losses were unaffected by forage meal inclusion in the diets (Lindberg \& Andersson, 1998). The same tendency was found by Stanogias \& Pearce (1985) when lucerne (Medicago sativa) was used to increase neutral-detergent fibre intake in diets for growing pigs. Also Lindberg et al. (1995) reported a significant increase in $\mathrm{N}$ retention when lucerne leaf meal replaced barley in a barley-based diet for growing pigs. The improved $\mathrm{N}$ utilization on barley-based diets with lucerne, white clover (Trifolium repens), red clover (Trifolium pratense) and perennial ryegrass (Lolium perenne) meal inclusion might be attributed to an improvement in the absorbed amino acid (AA) profile due to an increased intake of essential AA, as also shown by Reverter \& Lindberg (1998) for the barley-based diets with lucerne leaf meal inclusion. In this study (Reverter \& Lindberg, 1998), a high ileal apparent and true digestibility of $\mathrm{AA}$ in lucerne leaf meal was found, resulting in an improvement in the absorbed AA profile due to a significant increase in the absorption of all of the essential AA.

The objective of the present experiments was to study the ileal digestibility of AA in growing pigs fed on a barleybased diet with inclusion of either 100 or $200 \mathrm{~g} / \mathrm{kg}$ lucerne, white clover, red clover or perennial ryegrass.

\section{Materials and methods}

\section{Animals and their management}

Ten cross-bred (Yorkshire $\times$ Swedish Landrace) castrated male pigs were used. They were grouped in two separate experiments with five pigs in each. The average live weights were $41(\mathrm{SD} 4.9) \mathrm{kg}$ and $74(\mathrm{SD} 6.7) \mathrm{kg}$ respectively at the start and termination of Expt 1, and 43 (SD 1.5) kg and 79 (SD $5 \cdot 3) \mathrm{kg}$ respectively for Expt 2 . The pigs were surgically fitted with post-valve T-caecum cannulas (van Leeuwen et al. 1991) to allow collection of ileal digesta. Experimental diets were introduced to the pigs 2 weeks post-surgery. The pigs were housed individually in $3.5 \mathrm{~m}^{2}$ pens equipped with rubber mats, and during digesta collection they were restricted to a limited space within the pen. The room had a controlled temperature of $18^{\circ}$ and a controlled light regimen (07.00-19.00 hours). The experiment was approved by the Ethical Committee for Animal Experiments in Uppsala.

\section{Diets and feeding}

The ingredient compositions of the experimental diets used in Expts 1 and 2 are shown in Table 1. The chemical compositions of the forages and the experimental diets used in both experiments are presented Table 1 and the compositions $(\mathrm{g} / 16 \mathrm{~g} \mathrm{~N})$ of essential AA and nonessential AA in protein from barley and forages are presented in Table 2. The control diets ( $\mathrm{C} 1$ and $\mathrm{C} 2$ ) were composed of barley $(950 \mathrm{~g} / \mathrm{kg})$ from the same batch, while the other diets contained barley and either of two levels $(100 \mathrm{~g} / \mathrm{kg}$ and $200 \mathrm{~g} / \mathrm{kg}$ ) of lucerne (L10 and L20) or white clover (W10 
Table 2. Content of essential and nonessential amino acids $(\mathrm{g} / 16 \mathrm{~g} \mathrm{~N})$ in barley, lucerne, white clover, red clover and perennial ryegrass

\begin{tabular}{|c|c|c|c|c|c|c|}
\hline \multirow[b]{2}{*}{ Amino acids* } & \multicolumn{3}{|c|}{ Expt 1} & \multicolumn{3}{|c|}{ Expt 2} \\
\hline & Barley & Lucerne & White clover & Barley & Red clover & Perennial ryegrass \\
\hline \multicolumn{7}{|c|}{ Essential amino acids } \\
\hline Arginine & 5.2 & 4.2 & $5 \cdot 1$ & $5 \cdot 1$ & 4.4 & 4.4 \\
\hline Cystine & 4.2 & 2.9 & $2 \cdot 7$ & 4.2 & $2 \cdot 1$ & $2 \cdot 5$ \\
\hline Isoleucine & 3.5 & $4 \cdot 1$ & 4.2 & 3.5 & $4 \cdot 1$ & 4.0 \\
\hline Leucine & $6 \cdot 7$ & $6 \cdot 4$ & $6 \cdot 8$ & $6 \cdot 6$ & $6 \cdot 6$ & $6 \cdot 8$ \\
\hline Lysine & 3.7 & 4.5 & 4.5 & 3.7 & 4.4 & 3.9 \\
\hline Histidine & $2 \cdot 1$ & $2 \cdot 1$ & $2 \cdot 3$ & $2 \cdot 2$ & $2 \cdot 1$ & $1 \cdot 7$ \\
\hline Methionine & 1.6 & 1.4 & 1.3 & 1.6 & 1.2 & 1.5 \\
\hline Phenylalanine & $5 \cdot 1$ & 4.7 & 4.6 & $5 \cdot 1$ & 4.9 & 4.5 \\
\hline Threonine & 3.5 & 3.9 & $3 \cdot 6$ & 3.5 & $3 \cdot 6$ & 3.6 \\
\hline Tyrosine & 3.2 & $3 \cdot 3$ & 3.3 & 3.2 & 3.3 & $2 \cdot 7$ \\
\hline Valine & 4.9 & $5 \cdot 1$ & $5 \cdot 1$ & $4 \cdot 8$ & $5 \cdot 1$ & $5 \cdot 3$ \\
\hline \multicolumn{7}{|c|}{ Nonessential amino acids } \\
\hline Alanine & 3.6 & 4.7 & 4.6 & 3.7 & 4.8 & $5 \cdot 3$ \\
\hline Aspartic acid & 5.4 & $12 \cdot 8$ & $11 \cdot 2$ & 5.9 & $11 \cdot 3$ & 8.2 \\
\hline Glutamic acid & 21.9 & 8.2 & $9 \cdot 1$ & $22 \cdot 2$ & 8.5 & $10 \cdot 0$ \\
\hline Glycine & 3.8 & $4 \cdot 1$ & 4.5 & 3.9 & 4.2 & 4.0 \\
\hline Proline & $10 \cdot 6$ & $7 \cdot 7$ & $8 \cdot 3$ & $10 \cdot 8$ & $7 \cdot 1$ & 9.0 \\
\hline Serine & $4 \cdot 3$ & $4 \cdot 8$ & 4.4 & 4.4 & $4 \cdot 3$ & $4 \cdot 0$ \\
\hline
\end{tabular}

* Glucosamine and ornithine were not detected.

and W20) meal in Expt 1, and red clover (R10 and R20) or perennial ryegrass (PR10 and PR20) meal in Expt 2. These constituents replaced an equal weight of barley. The other ingredients of the diet were $(\mathrm{g} / \mathrm{kg})$ : vitamins and minerals 15, $\mathrm{Ca}_{2} \mathrm{PO}_{3} 20, \mathrm{CaCO}_{3} 8, \mathrm{NaCl} 4$, and $\mathrm{Cr}_{2} \mathrm{O}_{3} 3$ as a digesta flow marker.

Forages were grown in experimental plots at Uppsala and harvested at budding or early blooming, transferred into jute sacks and barn-dried at $25^{\circ}$ for at least $72 \mathrm{~h}$ or until dry. The barley and the forages were hammer-milled $(3.0 \mathrm{~mm}$ screen). After mixing, the diets were pelleted (inlet and outlet temperatures were approximately 75 and $80^{\circ}$ respectively). The pigs were given three equal meals per day (08.00, 16.00 and 24.00 hours). Daily feed allowance was restricted to $4 \%$ of mean body weight up to $75 \mathrm{~kg}$ live weight and thereafter $3 \mathrm{~kg} / \mathrm{d}$. Water was given ad libitum.

\section{Experimental design}

The experiments were conducted as $5 \times 5$ change-over designs (Patterson \& Lucas, 1962) as described earlier (Andersson \& Lindberg, 1997a,b) with experimental periods comprising $9 \mathrm{~d}$ of adaptation to each diet followed by $1 \mathrm{~d}$ of collection of ileal digesta, $1 \mathrm{~d}$ of rest and then one further day of collection of ileal digesta.

\section{Digesta collection and calculations}

Ileal digesta samples were collected for $1 \mathrm{~h}$ every third hour during a $24 \mathrm{~h}$ collection period, making a total of sixteen samples for each pig and experimental period. Samples were collected in a plastic jar which was emptied into a larger container placed in crushed ice. The ileal digesta samples were weighed, homogenized and immediately frozen $\left(-20^{\circ}\right)$ after every collection hour. After the collection period, the samples were thawed, subsampled and freeze-dried.
Ileal digesta flows were estimated assuming a complete recovery of $\mathrm{Cr}_{2} \mathrm{O}_{3}$ at the terminal ileum.

The digestibilities of AA in the forage meals (lucerne, white clover, red clover and perennial ryegrass) were estimated by difference. The average digestibility values of AA for all five periods for the control diet, within experiment (Expts 1 and 2), were used to estimate the digestibility of the essential AA in forage meals in individual pigs and periods in each experiment. Calculations were done according to the following equation:

$$
\mathrm{D}_{\mathrm{F}}=\mathrm{D}_{\text {exp. }}-\left(\mathrm{AA}_{\mathrm{C}} \times \mathrm{D}_{\mathrm{C}}\right) / \mathrm{AA} \mathrm{F}_{\mathrm{F}}
$$

where $\mathrm{D}_{\mathrm{F}}$ is the AA digestibility in the forage meal, $\mathrm{D}_{\text {exp. }}$ is the AA digestibility in each experimental diet, $\mathrm{AA}_{\mathrm{C}}$ is the amount of AA ingested from barley in each experimental diet, $\mathrm{D}_{\mathrm{C}}$ is the AA digestibility in the control diet and $\mathrm{AA}_{\mathrm{F}}$ is the amount of AA ingested from the forage meal in each experimental diet.

\section{Chemical analysis}

All feed and digesta analyses were performed on freezedried samples. Chemical analyses were performed according to conventional procedures as described by Andersson \& Lindberg (1997a). Dietary fibre and Klason lignin were analysed according to Theander et al. (1995). Crude protein (CP) (Kjeldahl $\mathrm{N} \times 6.25)$ was determined according to Nordisk Metodikkommitté (1976).

$\mathrm{AA}$ in feed and ileal digesta were analysed by HPLC according to Cohen \& De Antonis (1994). Samples were hydrolysed for $24 \mathrm{~h}$ at $110^{\circ}$ with $6 \mathrm{M}-\mathrm{HCl}$ containing $2 \mathrm{mg} / \mathrm{ml}$ reagent grade phenol and $5000 \mathrm{nmol}$ norleucine (internal standard) in evacuated and sealed ignition tubes. Half-cystine and methionine were determined as cysteic acid and methionine sulfone respectively, with separate samples oxidized with performic acid overnight at $0^{\circ}$ and 


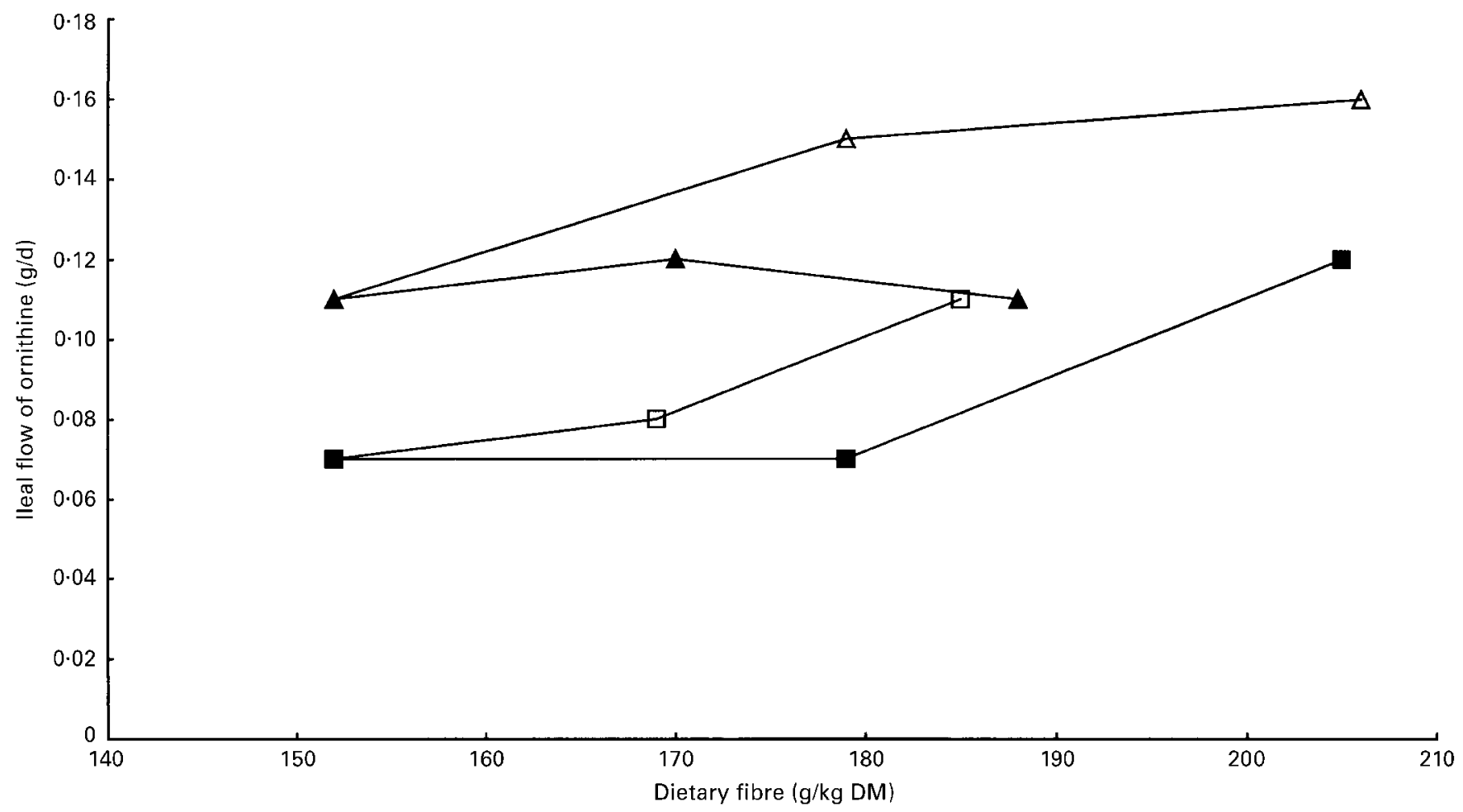

Fig. 1. lleal flow of ornithine ( $\mathrm{g} / \mathrm{d})$ with increasing fibre content (g/kg DM in a barley-based diet with inclusion of lucerne $(\square)$, white clover $(\square)$, red clover $(\boldsymbol{\Lambda})$ and perennial ryegrass $(\triangle)$ meals.

thereafter hydrolysed for $24 \mathrm{~h}$ as described earlier (Moore, 1963).

$\mathrm{Cr}$ was determined with emission spectrophotometry on diluted samples, using the inductively-coupled plasma technique, after digesting the ashed samples in $14.8 \mathrm{M}-$ phosphoric acid according to Bock (1979). All results are presented on a DM basis.

\section{Statistical analysis}

ANOVA were performed according to a $5 \times 5$ Latin-square design within experiment using the GLM procedure (Statistical Analysis Systems Inc., Cary, NC, USA). Treatment mean comparisons were tested with least squares means (Statistical Analysis Systems Inc.). Results are presented as least squares means with their standard errors.

\section{Results}

\section{Daily intake of DM, crude protein and amino acids}

In Expt 1 the diets were consumed without problems except for two pigs (each in one period only). One pig, which showed discomfort with the cannula, was replaced, resulting in a high variation in DM intakes (SEM $35 \mathrm{~g} / \mathrm{d}$ ) across experimental diets (data not shown).

In Expt 2 all pigs completely consumed their feed allowances without any refusals and as a result of differences in the chemical composition of the diets, minor differences in DM intake occurred $(P<0.05)$ (Table 1). However, due to a higher content of $\mathrm{CP}$ (Table 1) and subsequently higher content of most of the essential AA in the forages compared with the barley-based diets (Table 2), the intake of CP (Table 1), as well as most of the essential AA (data not shown), increased significantly $(P<0.05)$ in both experiments (from 18 to $160 \mathrm{~g} / \mathrm{kg}$ diet) when the dietary content of forages was increased. The intake of essential AA was higher for the pigs fed on the diets with inclusion of white clover meal in Expt 1 (70$90 \mathrm{~g} / \mathrm{kg}$ diet) and red clover meal in Expt $2(50-130 \mathrm{~g} / \mathrm{kg}$ diet) compared with the pigs fed on the diets with inclusion of lucerne and perennial ryegrass meal respectively (data not shown).

\section{Ileal flow of crude protein, amino acids and glucosamine}

There was an increase $(P<0.05)$ in the apparent ileal flow of $\mathrm{CP}$ and all amino acids with increasing inclusion of forage meals (data not shown). The ileal flow of ornithine (non-dietary AA) tended to increase with the inclusion of forage meals (Fig. 1), but the increase was only found to be significant $(P<0.05)$ with the inclusion of $200 \mathrm{~g}$ lucerne meal $/ \mathrm{kg}$ diet in Expt 1 and with the inclusion of perennial ryegrass in Expt 2 (data not shown).

In addition, the ileal flow of glucosamine (a non-dietary aminosugar) increased $(P<0.05)$ with the inclusion of all of the forage meals and was related to the content of dietary fibre (Fig. 2). 


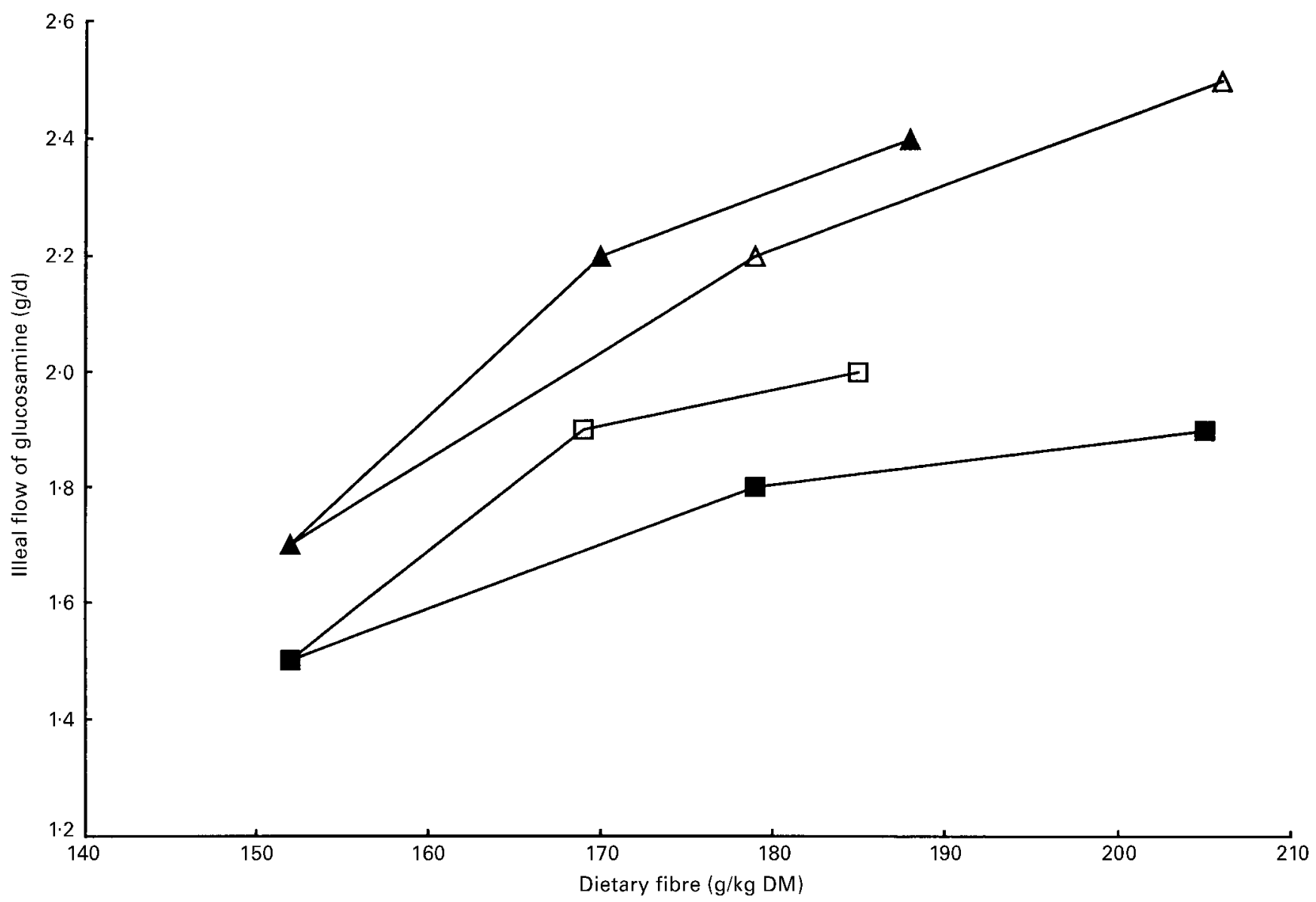

Fig. 2. Ileal flow of glucosamine ( $\mathrm{g} / \mathrm{d})$ with increasing fibre content $(\mathrm{g} / \mathrm{kg} \mathrm{DM})$ in a barley-based diet with inclusion of lucerne ( $\mathbf{\square})$, white clover $(\square)$, red clover $(\boldsymbol{\Lambda})$ and perennial ryegrass $(\Delta)$ meals.

\section{Apparent crude protein and amino acid digestibilities}

In Expt 1 the inclusion of either lucerne or white clover in the barley-based diet reduced $(P<0.05)$ the ileal digestibilities of $\mathrm{CP}$ and most of the essential AA and nonessential AA. However, the depression in ileal digestibility was only significant $(P<0.05)$ when the inclusion of forage meal was $200 \mathrm{~g} / \mathrm{kg}$ diet, with the exception of proline, for which the digestibility was significantly $(P<0.05)$ depressed at inclusion of lucerne meal at $100 \mathrm{~g} / \mathrm{kg}$ diet. No significant reduction was found in the ileal digestibilities of histidine and methionine with the inclusion of lucerne, while with the inclusion of white clover, isoleucine and glycine digestibilities were unaffected. The ileal digestibilities of tyrosine, alanine and aspartic acid did not decrease significantly on any of the diets (Table 3).

In Expt 2 the inclusion of red clover and perennial ryegrass had different effects. With the inclusion of red clover, only the digestibilities of $\mathrm{CP}$, leucine, phenylalanine, tyrosine and glutamic acid showed a depression $(P<0.05)$. In contrast, with the inclusion of perennial ryegrass the ileal digestibilities of $\mathrm{CP}$ and all essential $\mathrm{AA}$ and nonessential AA, with the exception of threonine, alanine and glutamic acid, decreased $(P<0.05)$ with the inclusion level of $200 \mathrm{~g} / \mathrm{kg}$ and also at $100 \mathrm{~g} / \mathrm{kg}$ inclusion of $\mathrm{CP}$ and serine (Table 4).

\section{Estimated apparent amino acid digestibilities of forage meals}

Apparent ileal digestibilities of essential AA in the forage meals estimated by difference were lower than in the barleybased diet, with the exception of the apparent digestibilities of isoleucine and of threonine in red clover. Significant $(P<0.05)$ differences in digestibility were found only for cystine in red clover and perennial ryegrass in Expt 2 (Table 5).

\section{Discussion}

The apparent ileal digestibilities of AA in the control diets in the present work were comparable with other published values for barley and barley-based diets (Sauer et al. 1977; Taverner et al. 1981a; Reverter \& Lindberg, 1998). The AA digestibilities, as well as the $\mathrm{CP}$ digestibility in the control diet in Expt 2, were lower than in Expt 1. This might be due to animal factors as the barley used in the experimental diets was from the same batch and the AA composition was found to be similar in both diets. In the present study there were only minor changes in apparent ileal AA digestibilities when forage meals substituted for barley in barley-based diets, although the estimated apparent ileal digestibilities of AA in the forage meals were lower compared with barley. This was in agreement with Reverter \& Lindberg (1998) 
Table 3. Apparent ileal digestibilities of crude protein and essential and nonessential amino acids in experiment 1

\begin{tabular}{lllllll}
\hline & \multicolumn{5}{c}{ Diets } \\
\cline { 2 - 7 } & \multicolumn{7}{c}{ C1 } & L10 & L20 & W10 & W20 & SEM \\
\hline Crude protein & $0.66^{\mathrm{a}}$ & $0.64^{\mathrm{ab}}$ & $0.59^{\mathrm{c}}$ & $0.65^{\mathrm{ab}}$ & $0.61^{\mathrm{bc}}$ & 0.014 \\
Essential amino acids & & & & & & \\
Arginine & $0.81^{\mathrm{a}}$ & $0.79^{\mathrm{abc}}$ & $0.79^{\mathrm{bc}}$ & $0.81^{\mathrm{ab}}$ & $0.78^{\mathrm{c}}$ & 0.008 \\
Cystine & $0.80^{\mathrm{a}}$ & $0.79^{\mathrm{ab}}$ & $0.74^{\mathrm{c}}$ & $0.80^{\mathrm{a}}$ & $0.75^{\mathrm{bc}}$ & 0.012 \\
Histidine & $0.78^{\mathrm{a}}$ & $0.78^{\mathrm{a}}$ & $0.76^{\mathrm{ab}}$ & $0.78^{\mathrm{a}}$ & $0.74^{\mathrm{b}}$ & 0.009 \\
Isoleucine & $0.76^{\mathrm{ab}}$ & $0.77^{\mathrm{a}}$ & $0.73^{\mathrm{b}}$ & $0.76^{\mathrm{a}}$ & $0.74^{\mathrm{ab}}$ & 0.009 \\
Leucine & $0.81^{\mathrm{a}}$ & $0.80^{\mathrm{ab}}$ & $0.78^{\mathrm{bc}}$ & $0.80^{\mathrm{ab}}$ & $0.77^{\mathrm{bc}}$ & 0.009 \\
Lysine & $0.82^{\mathrm{a}}$ & $0.81^{\mathrm{ab}}$ & $0.79^{\mathrm{b}}$ & $0.81^{\mathrm{ab}}$ & $0.78^{\mathrm{b}}$ & 0.010 \\
Methionine & $0.77^{\mathrm{a}}$ & $0.75^{\mathrm{ab}}$ & $0.74^{\mathrm{ab}}$ & $0.74^{\mathrm{ab}}$ & $0.72^{\mathrm{b}}$ & 0.016 \\
Phenylalanine & $0.83^{\mathrm{a}}$ & $0.82^{\mathrm{a}}$ & $0.80^{\mathrm{b}}$ & $0.83^{\mathrm{a}}$ & $0.80^{\mathrm{b}}$ & 0.006 \\
Threonine & $0.62^{\mathrm{a}}$ & $0.59^{\mathrm{ab}}$ & $0.56^{\mathrm{b}}$ & $0.58^{\mathrm{ab}}$ & $0.55^{\mathrm{b}}$ & 0.016 \\
Tyrosine & 0.79 & 0.79 & 0.77 & 0.78 & 0.76 & 0.008 \\
Valine & $0.77^{\mathrm{a}}$ & $0.77^{\mathrm{a}}$ & $0.74^{\mathrm{b}}$ & $0.77^{\mathrm{a}}$ & $0.74^{\mathrm{b}}$ & 0.008 \\
Nonessential amino acids & & & & & & \\
Alanine & $0.66^{\mathrm{b}}$ & 0.68 & 0.66 & 0.68 & 0.67 & 0.011 \\
Aspartic acid & $0.70^{\mathrm{b}}$ & $0.74^{\mathrm{ab}}$ & $0.76^{\mathrm{a}}$ & $0.72^{\mathrm{b}}$ & $0.73^{\mathrm{ab}}$ & 0.008 \\
Glutamic acid & $0.87^{\mathrm{a}}$ & $0.85^{\mathrm{a}}$ & $0.84^{\mathrm{b}}$ & $0.86^{\mathrm{a}}$ & $0.83^{\mathrm{b}}$ & 0.005 \\
Glycine & $0.57^{\mathrm{a}}$ & $0.52^{\mathrm{ab}}$ & $0.47^{\mathrm{b}}$ & $0.55^{\mathrm{a}}$ & $0.51^{\mathrm{ab}}$ & 0.024 \\
Proline & $0.60^{\mathrm{a}}$ & $0.47^{\mathrm{bc}}$ & $0.39^{\mathrm{c}}$ & $0.55^{\mathrm{ab}}$ & $0.48^{\mathrm{bc}}$ & 0.039 \\
Serine & $0.74^{\mathrm{a}}$ & $0.73^{\mathrm{ab}}$ & $0.71^{\mathrm{b}}$ & $0.73^{\mathrm{ab}}$ & $0.71^{\mathrm{b}}$ & 0.009 \\
\hline
\end{tabular}

$\overline{a, b, c}$ Mean values within a row not sharing a common superscript letter were significantly different $(P<0.05)$.

who studied lucerne leaf meal included in a barley-based diet for growing pigs. In the present work the apparent ileal essential AA digestibilities of the forage meals were on average $0 \cdot 82-0.84$ of the apparent ileal essential AA digestibility of barley in Expt 1 and $0.83-0.91$ in Expt 2 . It is suggested that this reflects the potential supply of ileal digestible essential AA from forage meal protein in diets for growing pigs.

The levels of $\mathrm{CP}$ and most of the essential AA in the forages studied were higher compared with barley which resulted in higher intakes of $\mathrm{CP}$ and most of the essential AA. The higher protein intake after inclusion of forage meal in the diet may have been influencing positively the ileal digestibility coefficients obtained for those diets compared with the control diet. However, we consider the differences in $\mathrm{CP}$ intake to be too small to have resulted in any significant influence on the digestibility of the forage meals. The increase in the ileal flow of the AA resulting

Table 4. Apparent ileal digestibilities of crude protein and essential and nonessential amino acids in experiment 2

\begin{tabular}{lllllll}
\hline & \multicolumn{5}{c}{ Diets } \\
\cline { 2 - 7 } & C2 & R10 & R20 & PR10 & PR20 & SEM \\
\hline Crude protein & $0.56^{\mathrm{a}}$ & $0.54^{\mathrm{ab}}$ & $0.50^{\mathrm{b}}$ & $0.51^{\mathrm{b}}$ & $0.42^{\mathrm{c}}$ & 0.014 \\
Essential amino acids & & & & & & \\
Arginine & $0.77^{\mathrm{a}}$ & $0.77^{\mathrm{a}}$ & $0.75^{\mathrm{ab}}$ & $0.77^{\mathrm{a}}$ & $0.73^{\mathrm{b}}$ & 0.009 \\
Cystine & $0.75^{\mathrm{a}}$ & $0.75^{\mathrm{a}}$ & $0.75^{\mathrm{a}}$ & $0.74^{\mathrm{a}}$ & $0.71^{\mathrm{b}}$ & 0.004 \\
Histidine & $0.73^{\mathrm{a}}$ & $0.73^{\mathrm{a}}$ & $0.70^{\mathrm{a}}$ & $0.73^{\mathrm{a}}$ & $0.66^{\mathrm{b}}$ & 0.012 \\
Isoleucine & $0.71^{\mathrm{a}}$ & $0.72^{\mathrm{a}}$ & $0.70^{\mathrm{ab}}$ & $0.71^{\mathrm{a}}$ & $0.68^{\mathrm{b}}$ & 0.007 \\
Leucine & $0.75^{\mathrm{ab}}$ & $0.75^{\mathrm{a}}$ & $0.73^{\mathrm{bc}}$ & $0.74^{\mathrm{a}}$ & $0.72^{\mathrm{c}}$ & 0.006 \\
Lysine & $0.76^{\mathrm{a}}$ & $0.76^{\mathrm{a}}$ & $0.76^{\mathrm{a}}$ & $0.75^{\mathrm{a}}$ & $0.72^{\mathrm{b}}$ & 0.006 \\
Methionine & $0.73^{\mathrm{a}}$ & $0.73^{\mathrm{a}}$ & $0.71^{\mathrm{ab}}$ & $0.69^{\mathrm{ab}}$ & $0.66^{\mathrm{b}}$ & 0.021 \\
Phenylalanine & $0.79^{\mathrm{a}}$ & $0.79^{\mathrm{a}}$ & $0.76^{\mathrm{b}}$ & $0.78^{\mathrm{ab}}$ & $0.76^{\mathrm{b}}$ & 0.008 \\
Threonine & 0.61 & 0.61 & 0.61 & 0.60 & 0.57 & 0.016 \\
Tyrosine & $0.74^{\mathrm{a}}$ & $0.73^{\mathrm{ab}}$ & $0.71^{\mathrm{bc}}$ & $0.73^{\mathrm{ab}}$ & $0.70^{\mathrm{c}}$ & 0.007 \\
Valine & $0.72^{\mathrm{a}}$ & $0.72^{\mathrm{a}}$ & $0.71^{\mathrm{ab}}$ & $0.72^{\mathrm{a}}$ & $0.70^{\mathrm{b}}$ & 0.007 \\
Nonessential amino acids & & & & & & \\
Alanine & $0.62^{\mathrm{b}}$ & 0.62 & 0.61 & 0.61 & 0.59 & 0.017 \\
Aspartic acid & $0.69^{\mathrm{ab}}$ & $0.73^{\mathrm{a}}$ & $0.71^{\mathrm{a}}$ & $0.69^{\mathrm{ab}}$ & $0.67^{\mathrm{b}}$ & 0.014 \\
Glutamic acid & $0.85^{\mathrm{a}}$ & $0.84^{\mathrm{ab}}$ & $0.83^{\mathrm{b}}$ & $0.84^{\mathrm{ab}}$ & $0.85^{\mathrm{ab}}$ & 0.006 \\
Glycine & $0.47^{\mathrm{a}}$ & $0.45^{\mathrm{ab}}$ & $0.42^{\mathrm{ab}}$ & $0.47^{\mathrm{a}}$ & $0.37^{\mathrm{b}}$ & 0.028 \\
Proline & $0.51^{\mathrm{a}}$ & $0.44^{\mathrm{ab}}$ & $0.41^{\mathrm{ab}}$ & $0.43^{\mathrm{ab}}$ & $0.36^{\mathrm{b}}$ & 0.045 \\
Serine & $0.73^{\mathrm{a}}$ & $0.72^{\mathrm{ab}}$ & $0.71^{\mathrm{ab}}$ & $0.67^{\mathrm{b}}$ & $0.61^{\mathrm{c}}$ & 0.016 \\
\hline
\end{tabular}

${ }_{a, b, c}$ Mean values within a row not sharing a common superscript letter were significantly different $(P<0.05)$. 
Ileal amino acid digestibilities in pigs

Table 5. Apparent ileal digestibilities of essential amino acids in the forage meals

\begin{tabular}{lccccccr}
\hline & \multicolumn{3}{c}{ Expt 1 } & & \multicolumn{2}{c}{ Expt 2 } \\
\cline { 2 - 3 } & Lucerne & White clover & SEM & & Red clover & Perennial ryegrass & SEM \\
\hline Arginine & 0.67 & 0.76 & 0.060 & & 0.62 & 0.67 & 0.070 \\
Cystine & 0.54 & 0.59 & 0.080 & & $0.74^{\mathrm{a}}$ & $0.54^{\mathrm{b}}$ & 0.063 \\
Histidine & 0.74 & 0.69 & 0.061 & & 0.57 & 0.62 & 0.078 \\
Isoleucine & 0.73 & 0.73 & 0.051 & & 0.75 & 0.66 & 0.047 \\
Leucine & 0.65 & 0.60 & 0.034 & & 0.68 & 0.64 & 0.045 \\
Lysine & 0.71 & 0.71 & 0.048 & 0.76 & 0.64 & 0.043 \\
Methionine & 0.31 & 0.53 & 0.140 & & 0.61 & 0.45 & 0.110 \\
Phenylalanine & 0.72 & 0.69 & 0.054 & 0.72 & 0.65 & 0.052 \\
Threonine & 0.49 & 0.44 & 0.110 & 0.64 & 0.49 & 0.110 \\
Tyrosine & 0.74 & 0.68 & 0.043 & & 0.55 & 0.61 & 0.051 \\
Valine & 0.70 & 0.75 & 0.048 & & 0.70 & 0.68 & 0.045 \\
\hline
\end{tabular}

${ }^{\mathrm{a}, \mathrm{b}}$ Mean values within a row with unlike superscript letters were significantly different $(P<0.05)$.

after feeding the diets with forage meal inclusion was found to be proportionally higher than the increase in AA intakes, as was also reported by Reverter \& Lindberg (1998), when lucerne leaf meal was included in a barley-based diet. This relative difference may be attributed to a higher content of fibre in the experimental diets, which can impair digestion and absorption of the dietary components by increasing the rate of digesta flow (Kass et al. 1980; Kuan et al. 1983; Stanoigas \& Pearce, 1985), acting as a physical barrier for the digestive enzymes (Shah et al. 1982) and decreasing the diffusion of nutrients towards the mucosal surfaces (Bergner, 1982; Rérat, 1991; Sauer et al. 1991).

The highest ileal AA proportions were found for proline and glycine, which are the major contributors to the metabolic AA losses (Holmes et al. 1974; Wünsche et al. 1987). Moreover, a significant increment in the ileal flow of glucosamine was found when the forage meals were included in the barley-based diet. This was in agreement with Cassidy et al. (1981), Mariscal-Landín et al. (1995) and Reverter \& Lindberg (1998) showing an increase in the flow of aminosugars at the ileum of pigs with increasing fibre intake. The aminosugars are the major component of the mucins and make the greatest contribution to the ileal endogenous losses of nitrogenous compounds because of their resistance to digestion and recycling (Fuller \& Cadenhead, 1991). Mucin proteins are rich in proline, glycine, threonine and serine (Horowitz, 1967) and glycine is the predominant AA in bile secretion (Juste, 1982). Thus, the high levels of proline and glycine found at the terminal ileum of pigs fed on diets with $200 \mathrm{~g} / \mathrm{kg}$ inclusion of forage meals, together with the increase in the glucosamine flow, provide indirect evidence that the endogenous losses and mucus production were somewhat enhanced. However, it has been shown that an increase in aminosugar secretion does not necessarily imply an increase in amino acid endogenous losses (Mariscal-Landín et al. 1995). It should also be pointed out that the increase in endogenous $\mathrm{N}$ found at the terminal ileum may be due to an enhanced $\mathrm{N}$ secretion and/or a decrease in the rate of reabsorption of the metabolic N (Grala et al. 1998).

Mucin is secreted in the intestinal lumen by goblet cells, the number of which appears to increase after feeding dietary fibre (Schneeman, 1982). Therefore, changes in mucin content and/or composition at the mucosal surface might also impair the rate of nutrient absorption induced by fibre feeding (Satchithanandam et al. 1990).

When comparing the proportions of proline and glycine found at the ileum after the inclusion of the different forages, a higher amount of these AA was found in the pigs fed on the barley-based diet with $200 \mathrm{~g} / \mathrm{kg}$ inclusion of lucerne and perennial ryegrass compared with white and red clover meals. The proportion found in the clover meals was similar to that found with the inclusion of lucerne leaf meal (Reverter \& Lindberg, 1998). These differences might be due to the fibre level in the diets and to the composition and properties of the different forage fibres.

Glucosamine is also a component of the bacterial cell wall (Ewing \& Cole, 1994) and changes in the amount of this compound might also be related to changes in microbial activity. An increase in microbial activity in the small intestine of pigs when fed on high-fibre compared with low-fibre diets appears likely (Borg Jensen \& Jørgensen, 1994). An increase in the ileal flow of the non-dietary AA ornithine on diets L20, PR10 and PR20 compared with the control diet in the present experiment gives indirect support to this contention, as it has been shown that ornithine is produced by the gut microflora from arginine (Fay \& Barry, 1972).

Conflicting results have been reported after feeding different levels of fibre to pigs in relation to AA digestibility and endogenous secretion. According to Sauer et al. (1977), Taverner et al. (1981b) and Mariscal-Landín et al. (1995), the levels of neutral-detergent fibre used in the present experiment should not induce an increase in endogenous AA losses. Schulze et al. (1994, 1995), on the other hand, found a linear increase in endogenous ileal $\mathrm{N}$ secretion with increasing levels of neutral-detergent fibre in experimental diets of up to $200 \mathrm{~g} / \mathrm{kg}$ DM. These discrepancies could be due to the inclusion of different fibre sources in the referred studies. When comparing the AA digestibilities in the diets with inclusion of clover meals in the present study, the AA digestibilities found in W20 appeared to be more negatively affected than in R20, even though there were no differences in the content of total dietary fibre. The explanation might be the higher content of lignin present in white clover compared with red clover meal. This supports the fact that the amount as well as the type of dietary fibre, including degree of lignification (Farrell, 1973), and also the basal diet 
used in the different studies, are important factors determining the effect of the fibre on AA digestion, endogenous losses (Sauer \& Ozimek, 1986) and rate of food passage (Potkins et al. 1991).

Available data make it difficult to conclude which factors might be more important in influencing the decrease in AA digestibilities in diets with forage meal inclusion compared with the barley-based diets. It appears likely that all the factors discussed earlier might be involved to a major or minor extent depending on the particular forage meal included in the diet. It should be noted, however, that with the minor changes found in ileal essential AA digestibilities with forage meal inclusion in the diet, the present data confirm the potential of forage meals as a source of protein in pig diets.

\section{Acknowledgements}

We express our sincere thanks to Dr Sigvard Thomke and Dr Horacio L. Gonda for valuable discussions and criticism of the manuscript. This work has been financially supported by the Swedish Council for Forestry and Agricultural Research.

\section{References}

Åman P \& Graham H (1990) Chemical evaluation of polysaccharides in animal feeds. In Feedstuff Evaluation, pp. 161-177 [J Wiseman and DJA Cole, editors]. Cambridge: University Press Ltd.

Andersson C \& Lindberg JE (1997a) Forages in diets for growing pigs. 1. Nutrient apparent digestibilities and partition of nutrient digestion in barley-based diets including lucerne and white clover meal. Animal Science 65, 483-491.

Andersson C \& Lindberg JE (1997b) Forages in diets for growing pigs. 2. Nutrient apparent digestibilities and partition of nutrient digestion in barley-based diets including red-clover and perennial ryegrass meal. Animal Science 65, 493-500.

Beames RM \& Eggum BO (1981) The effect of type and level of protein, fiber and starch on nitrogen excretion patterns in rats. British Journal of Nutrition 46, 301-313.

Bergner H (1982) Fiber and nitrogen excretion. In Physiologie Digestive Chez le Porc, no. 12, pp. 237-240 [JP Laplace, T Corring and A Rérat, editors]. Jouy-en-Josas, Versailles: Les Colloques de l'INRA.

Bock R (1979) A Handbook of Decomposition Methods in Analytical Chemistry. London: International Textbook Company.

Borg Jensen B \& Jørgensen H (1994) Effect of dietary fiber on microbial activity and microbial gas production in various regions of the gastrointestinal tract of pigs. Applied and Environmental Microbiology 60, 1897-1904.

Cassidy MM, Lightfoot FG \& Vahouny GV (1981) Structural and functional modulation of mucin secretory patterns in the gastrointestinal tract. In Membrane Biophysics. Structure and Function in Epithelia, pp. 97-127 [M Dinno, editor]. New York, NY: Alan R. Liss.

Cohen SA \& De Antonis KM (1994) Applications of amino acid derivatization with 6-aminoquinoly-N-hydroxysuccinimidyl carbamate. Analysis of feed grains, intravenous solutions and glycoproteins. Journal of Chromatography A 661, 25-34.

Ewing WN \& Cole DJA (1994) The Living Gut. Dungannon, Co Tyrone, N. Ireland: Context Publications.

Farrell DJ (1973) Digestibility by pigs of the major chemical components of diets high in plant cell-wall constituents. Animal Production 16, 43-47.
Fay GD \& Barry AL (1972) Rapid ornithine decarboxilase test for the identification of Enterobacteriaceae. Applied Microbiology 23, 710-713.

Frank GR, Aherne FX \& Jensen AH (1983) A study of the relationship between performance and dietary component digestibilities by swine fed different levels of dietary fiber. Journal of Animal Science 57, 645-654.

Fuller MF \& Cadenhead A (1991) Effect of the amount and composition of the diet on galactosamine flow from the small intestine. In Digestive Physiology in Pigs. Proceedings of the Fifth International Symposium on Digestive Physiology in Pigs, 1991. European Association for Animal Production Publication no. 54, pp. 330-333 [MWA Verstegen, J Huisman and LA den Hartog, editors]. Wageningen, The Netherlands: Wageningen, Pudoc.

Graham H (1988) Dietary fiber concentration and assimilation in swine. ISI Atlas of Science, Plant and Animal Science 1, 7680.

Grala W, Buraczewska L, Wasilewko J, Verstegen MWA, Tamminga S, Jansman AJM, Huisman J \& Korczynski W (1998) Flow of endogenous and exogenous nitrogen in different segments of the small intestine in pigs fed diets with soyabean concentrate, soyabean meal or rapeseed cake. Journal of Animal Science and Feed Science 7, 1-20.

Holmes JHG, Bayley HS \& Leadbeater PA (1974) Digestion of protein in small and large intestine of the pig. British Journal of Nutrition 32, 479-489.

Horowitz MI (1967) Handbook of Physiology: Section 6, Alimentary Canal [CF Code, editor]. Washington, DC: American Physiological Society.

Just A (1982a) The influence of crude fibre from cereals on the net energy value of diets for growth in pigs. Livestock Production Science 9, 569-580.

Just A (1982b) The influence of ground barley straw on the net energy value of diets for growth in pigs. Livestock Production Science 9, 717-729.

Juste C (1982) Apports endogenes par les sécretions digestives chez le porc (Endogenous contributions by digestive secretions in pigs). In Physilogie Digestive Chez le Porc, no. 12, pp. 155173 [JP Laplace, T Corring and A Rérat, editors]. Paris: Les Colloques de l'INRA.

Kass ML, Van Soest PJ, Pond WG, Lewis B \& McDowell RE (1980) Utilization of dietary fiber from alfalfa by growing swine. I. Apparent digestibility of diet components in specific segments of the gastrointestinal tract. Journal of Animal Science 50, 175191.

King RH \& Taverner MR (1975) Prediction of digestible energy in pig diets from analysis of fibre contents. Animal Production 21, 275-284.

Kuan KK, Stanogias G \& Dunkin AC (1983) The effect of proportion of cell-wall material from lucerne leaf meal on apparent digestibility, rate of passage and gut characteristics in pigs. Animal Production 36, 201-209.

Lindberg JE \& Andersson C (1998) The nutritive value of barleybased diets with forage meal inclusion for growing pigs based on total tract digestibility and nitrogen utilization. Livestock Production Science 56, 43-52.

Lindberg JE \& Cortova Z (1995) The effect of increasing inclusion of lucerne leaf meal in a barley-based diet on the partition of digestion and on nutrient utilisation in pigs. Animal Feed Science and Technology 56, 11-20.

Lindberg JE, Cortova Z \& Thomke S (1995) The nutritive value of lucerne leaf meal for pigs based on digestibility and nitrogen utilization. Acta Agriculturae Scandinavica Section A, Animal Science 45, 245-251.

Low AG (1993) Role of dietary fibre in pig diets. In Recent Developments in Pig Nutrition 2 [DJA Cole, W Haresign and 
PC Garnsworthy, editors]. Nottingham: Nottingham University Press.

Mariscal-Landín G, Sève B, Colléaux Y \& Lebreton Y (1995) Endogenous amino nitrogen collected from pigs with end-to-end ileorectal anastomosis is affected by the method of estimation and altered by dietary fibre. Journal of Nutrition 125, 136-146.

Moore S (1963) On the determination of cystine as cysteic acid. Journal of Biological Chemistry 238, 235-237.

Nordisk Metodikkommitté (1976) Nordic Committee on Food Analysis, no. 6, 3rd ed. Esbo, Finland.

Patersson DH \& Lucas HL (1962) Change Over-Designs. Technical Bulletin no. 147. Raleigh, NC: North Carolina Agricultural Experimental Station.

Potkins ZV, Lawrence TLJ \& Thomlinson JR (1991) Effects of structural polysaccharides in the diet of the growing pig on gastric emptying rate and rate of passage of digesta to the terminal ileum and through the total gastrointestinal tract. British Journal of Nutrition 65, 391-413.

Rérat A (1991) Carbohydrate interactions on protein and amino acid digestibility and absorption and metabolic consequences in the pig. Proceedings of the Sixth International Symposium on Protein Metabolism and Nutrition, 1991, European Association for Animal Production Publication no. 59, pp. 37-53 [BO Eggum, S Boisen, C Børsting, A Danfœr and T Hvelplund, editors]. Herning, Denmark: Research Center Foulum.

Reverter M \& Lindberg JE (1998) Ileal digestibility of amino acids in pigs given a barley-based diet with increasing inclusion of lucerne leaf meal. Animal Science 67, 131-138.

Satchithanandam S, Vargofcak-Apker M, Calvert RJ, Leeds AR \& Cassidy MM (1990) Alteration of gastrointestinal mucin by fiber feeding in rats. Journal of Nutrition 120, 1179-1184.

Sauer WC, Just A, Jorgensen H, Makonen Fekadu H \& Eggum BO (1980) The influence of diet composition on the apparent digestibility of crude protein and amino acids at the terminal ileum and overall in pigs. Acta Agriciculturae Scandinavica 30, 449-468.

Sauer WC, Mosenthin R, Ahrens F \& den Hartog LA (1991) The effect of source of fiber on ileal and fecal amino acid digestibility and bacterial nitrogen excretion in growing pigs. Journal of Animal Science 69, 4070-4077.

Sauer WC \& Ozimek L (1986) Digestibility of amino acids in swine: results and their practical applications. A review. Livestock Production Science 15, 367-388.

Sauer WC, Stothers SC \& Philips GD (1977) Apparent availabilities of amino acids in corn, wheat and barley for growing pigs. Canadian Journal of Animal Science 57, 585-597.

Schneeman BO (1982) Pancreatic and digestive function. In
Dietary Fiber in Health and Disease, pp. 73-83 [GV Vahouny and D Kritchevsky, editors]. New York, NY: Plenum Press.

Schulze H, van Leeuwen P, Verstegen MWA, Huisman J, Souffrant WB \& Ahrens F (1994) Effect of level of dietary neutral detergent fiber on ileal apparent digestibility and ileal nitrogen losses in pigs. Journal of Animal Science 72, 2362-2368.

Schulze H, van Leeuwen P, Verstegen MWA \& van den Berg JWO (1995) Dietary level and source of neutral detergent fiber and ileal endogenous nitrogen flow in pigs. Journal of Animal Science 73, 441-448.

Shah N, Mokhtar AT, Raymond RM \& Pellett PL (1982) Effect of dietary fibre components on fecal nitrogen excretion and protein utilisation in growing rats. Journal of Nutrition 112, 658-668.

Stanogias G \& Pearce GR (1985) The digestion of fibre by pigs. 1. The effects of amount and type of fibre on apparent digestibility, nitrogen balance and rate of passage. British Journal of Nutrition 53, 513-530.

Taverner MR, Hume ID \& Farrell DJ (1981a) Availability to pigs of amino acids in cereal grains. 2. Apparent and true ileal availability. British Journal of Nutrition 46, 159-171.

Taverner MR, Hume ID \& Farrell DJ (1981b) Availability to pigs of amino acids in cereal grains. 1. Endogenous levels of amino acis in ileal digesta and faeces of pigs given cereal diets. British Journal of Nutrition 46, 149-158.

Theander O, Aman P, Westerlund E, Andersson R \& Pettersson D (1995) Total dietary fiber determined as neutral sugars residues, uronic acid residues, and Klason lignin (The Uppsala Method): Collaborative study. Journal of AOAC International 78, 10301044.

Thomke S (1986) Swedish experiments on energy density in pig diets and with domestically grown protein feedstuffs. A review. World Review of Animal Production 22, 89-95.

van Leeuwen P, van Kleef DJ, van Kempen GJM, Huisman J \& Verstegen MWA (1991) The post-valve T-caecum cannulation technique in pigs applicated to determine digestibility of amino acid in maize, groundnut and sunflower meal. Journal of Animal Physiology and Animal Nutrition 65, 183-193.

Van Soest PJ (1978) Dietary fibers: Their definition and nutritional properties. American Journal of Clinical Nutrition 31, 512-520.

Wünshe J, Herrmann U, Meinl M, Hennig U, Kreinebring F \& Zwierz P (1987) Einfluss exogener Faktoren auf die präzäkale Nährstoff- und Aminosäurenresorption, ermittelt an Schweinen mit Ileo-Rektal-Anastomosen. 1. Mitt.: Einfluss des Zerkleinerungsgrades von Getreide (Influence of exogenous factors on the pre-caecal resorption of nutrients and amino acids in pigs with ileo-rectal anastamoses. 1. Influence of grain particle size. Archives of Animal Nutrition 37, 74-764. 